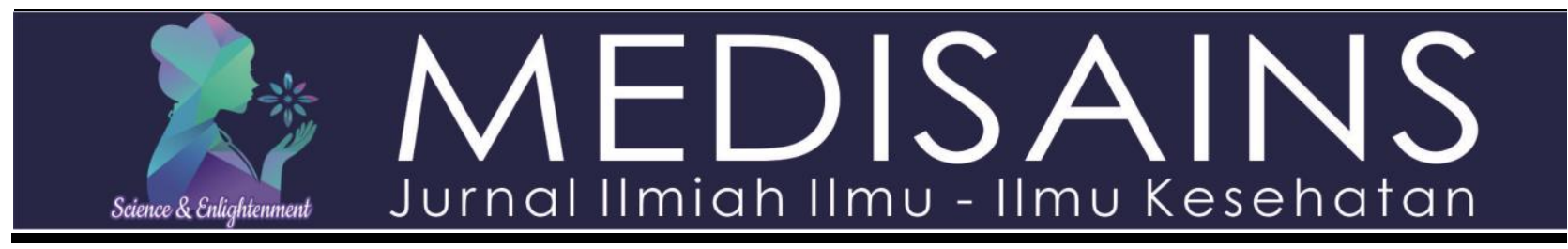

Original Article

\title{
Combination of pelvic floor and abdominal muscle exercises to reduce perineum pain in postpartum mothers Mariah Ulfah ${ }^{1}$, Dwi Novitasari, Murniati \\ ${ }^{1}$ Undergraduate Nursing Program, Health Faculty, Universitas Harapan Bangsa, Purwokerto, Jawa Tengah, Indonesia
}

\section{ARTICLE INFORMATION}

Received: Agustus 13, 2019

Revised: Agustus 27, 2019

Available online: Oktober 01, 2019

\section{KEYWORDS}

Perineum; Pelvic Floor; Exercise Therapy; Postpartum Period

\section{CORRESPONDENCE}

Phone: +6281327087508

E-mail: mariahulfah@uhb.ac.id

\section{A B S T R A C T}

Background: Perineum Pain risks a lack of rest time which will affect the reduction in milk production and can interfere with the process of uterine contractions which further risks the occurrence of subinvolution. Previous studies have only examined pelvic floor muscle exercises, however, they have not been combined with abdominal exercise. The combination of abdominal muscle exercises can increase the effectiveness of pelvic floor muscle performance so that it will improve blood circulation and make muscles relaxed and inhibit the increase in lactic acid due to muscle spasms and ischemic tissue that makes pain.

Objective: To find out the benefits of a combination of Pelvic Floor Muscle and Abdominal Muscle Exercises to Reduce Perineum Pain in Postpartum Mothers

Methods: This is a pre-experimental research with one group pretest-posttest design. The sample used was 16 people with random techniques. Statistical analysis was done by Wilcoxon while pain measurement was done by VAS instrument.

Results: The results showed the mean of the pain before doing the exercise was 3.94 and the mean of the pain after doing exercise was 1.62. From statistical test results by Wilcoxon test, it obtained a significance value of $0.003(p<0.05)$. Thus it was concluded that there were significant differences in perineum Pain before and after Pelvic Floor and Abdominal Muscle Exercises

Conclusion: Combination of pelvic floor muscle exercise and abdominal muscle can reduce perineum pain in postpartum mothers.

\section{INTRODUCTION}

During the puerperal, changes occur due to labor including changes in the perineum that can cause pain ${ }^{1}$. A research conducted in Australia on 215 women in the puerperal ward within 72 hours stated that $90 \%$ of them experienced perineum pain, $37 \%$ of them said they were in moderate or severe pain, and more than a third of women experienced moderate or severe perineum pain. The pain occurs mainly when walking (33\%) and when sitting (39\%) ${ }^{2}$.

Preliminary study conducted in the puerperal room of RSUD (Regional Hospital) Dr. R Goeteng Tarunadibrata from 31 October to 20 November 2017 in the puerperal room showed that from 45 postpartum mothers, there were almost $95 \%$ experiencing vaginal area pain due to suturing of the birth canal. When the patient was disturbed due to the pain, pharmacological approach was done by consuming analgesics.

Perineum pain is at risk of reduced rest time in the mother which will further risk of inadequate milk production. The pain also makes the mother afraid of elimination. It is known that when the elimination is not issued there will be a risk of subinvolution namely bleeding ${ }^{3}$. The approach taken to reduce perineum Pain is by consuming various analgesia, including a combination of ice packs $(69 \%)$, oral analgesia (75\%), narcotic analgesia (4\%) and anti-inflammatory suppositories $(25 \%)^{2}$. In fact, Pharmacological pain management is risky for infants because it enters the bloodstream which was then assembled in breast milk. Meanwhile, it is found that non-pharmacological method is much safer to apply because it has a lower risk and it does not cause side effects and uses physiological processes ${ }^{4}$ 
Non-pharmacological approaches that have been carried out are pain reduction with the application of ice ${ }^{4}$, Kegel exercises and deep breathing against perineum Pain ${ }^{5}$. According to other studies, it also found that the use of Kegel exercises after episiotomy is associated with less pain and less analgesic use ${ }^{6}$. However, it was found that some research relating to pelvic floor muscle exercises (Keagle) have not conducted with the combination of abdominal muscle exercises. Pelvic floor exercises combined with abdominal muscles will lead to optimal muscle work ${ }^{7}$. This exercise will increase oxygen circulation to the laceration area. Contractions and relaxation performed during this exercise will increase blood supply to the perineum tissue so that it can reduce pain in the perineum area ${ }^{8}$ and it can also provide vascularization to the uterus ${ }^{9}$

\section{METHOD}

\section{Study Design}

This study used a pre-experimental research design with a pre and posttest with control group design ${ }^{10}$. This study compared one treatment group namely before and after pelvic floor and abdominal exercises.

\section{Settings and Respondents}

The research was carried out at Goeteng Tarunadibrata Hospital, Purbalingga, from October to December 2018 or for 3 months. The population in this study was normal postpartum mothers within 24 hours was 45 postpartum mothers. The sample in experimental research was 10-20 people ${ }^{11}$. The number of samples taken is 16 people. The random sampling with inclusion criteria was conducted to vaginal puerperal patients with perineum pain in their first 24 hours. Furthermore, by using a random method, the researcher conducted a study on the postpartum pervaginam mothers by meeting them until the specified time period, namely on 12 December 2017.

\section{The Instrument and Measurement}

For pain measurement in this study were done by Visual Analoge Scale (VAS) instrument ${ }^{13}$. The steps of the pain measuruments were done before the patient's exercise, and immediately after the exercise of pelvic floor and abdominal muscles.

\section{Experimental Procedure}

Pelvic floor exercises refer to Kegel exercises 8 . Abdominal exercises are perfomed by contracting and relaxing abdominal muscles to improve pelvic floor muscles. Research shows that transversus abdominis (TA) and obliquus internus (OI) will improve pelvic floor muscles, due to an increase in intra-abdominal pressure with an average of $10 \mathrm{mmHg} 7$. This exercise is carried out for $3 x$ namely, 6 hours post partum, 12 hours post partum and 18 hours postpartum. Patients performed pelvic floor exercises according to standard operating procedures, then it was continued with abdominal exercises. Then pain was measured after exercise ${ }^{14}$.

\section{Data Analysis}

It uses the Wilcoxon test because the data were not normally distributed and they only use 1 variable.

\section{Ethical Consideration}

This research has passed the ethics test by the health research ethics committee of STIKes Harapan Bangsa

\section{RESULTS}

Based on table 1 above it can be seen that the majority $(75 \%)$ of respondents are in their healthy reproductive age, then most of them (56.2\%) are primiparous and the majority $(81.2 \%)$ experience perineum rupture. it was found a difference of the mean of perineum pain between before the treatment and after the treatment. The mean of perineum pain before the treatment of the combination of pelvic floor and abdominal muscle exercises was 3.94 while the mean of perineum pain after the treatment was 1.62 .

From table 2, it can be seen that 15 people with perineum Pain experience lower perineum pain after exercise than before exercise. It was found that 1 person had an increase in pain after exercise compared to before exercise. Then from the results of the Wilcoxon test statistic, a significance value of 0.001 ( $p<0.05$ ) was obtained, thus it was concluded that there was a significant difference in perineum Pain before and after pelvic and abdominal exercises.

\section{DISCUSSION}

The results showed that the average pain before the exercise was 3.94. The incidence of perineum trauma at delivery is $78 \%$. In addition, the majority of women with vaginal delivery experience some degree of perineum Pain after childbirth since it is related to the type and extent of trauma. However, it is also found that women without any perineum pain can also suffer extreme pain due to bruising or swelling. ${ }^{15}$, with some color changes in the area of hematoma ${ }^{16}$. About $85 \%$ of women who give birth spontaneously have vaginal trauma perineum. $32-33 \%$ of them was due to episiotomy with and $52 \%$ was due to spontaneous laceration ${ }^{17}$. These are due to stretching during childbirth due to pressure from the baby's head which can cause pain $^{4,18,19}$

From table 2 it can be seen that the mean pain after exercise was 1.62 and the Wilcoxon test results obtained a significance value of 0.001 ( $p<0.05)$, thus it was concluded that there were significant differences in perineum Pain before and after a combination of pelvic- 
Table 1. Characteristics of respondents

\begin{tabular}{lcc}
\hline Characteristics & Frequency & Percentage \\
\hline Age & & $25 \%$ \\
$<20$ years old & 4 & $75 \%$ \\
$20-35$ years old & 12 & $0 \%$ \\
$>35$ years old & 0 & $56.2 \%$ \\
Parity & 9 & $43.8 \%$ \\
Primipara & 7 & $0 \%$ \\
Multipara & 0 & $81.2 \%$ \\
Grandemultipara & & $18.8 \%$ \\
Rupture perineum & 13 & 3 \\
Rupture perineum & 3 & \\
Without rupture perineum & & \\
\hline
\end{tabular}

Table 2. Differences in perineum pain before and after combination of pelvic floor and abdominal muscle exercises ( $n=16$ )

\begin{tabular}{llccc}
\hline Variable & & $\mathbf{n}$ & Mean Rank & $\mathbf{p}$-value \\
\hline Pain after exercises & Negative Ranks & $15(\mathrm{a})$ & 8.83 & 0.001 \\
Pain before exercises & Positive Ranks & $1 \mathrm{~b}$ & 3.50 & \\
\hline
\end{tabular}

a: after exercise < before exercise

b: after exercise $>$ before exercise

c: after exercise $=$ before exercise

floor and abdominal muscle exercises. This is because this exercise will increase oxygen circulation to the laceration area. Contractions and relaxation performed during this exercise will increase blood supply to the perineum tissue so that it can reduce the pain in vaginal area ${ }^{20}$. Abdominal exercises are combined to strengthen during pelvic floor muscle training. Pelvic floor muscle training is an isometric strengthening exercise for pelvic floor muscles to counteract pelvic organ decline, to restore anatomical relations between the pelvic organs as before, and to maintain the balance of the abdominal muscles, back and lower quadrants which are vital for carry out rehabilitation programs 21. Pelvic floor and abdominal muscle exercises are safe to do by women after vaginal delivery and it can be done as soon as possible after the woman has just given birth or after the woman feels able to do so. Giving this strengthening exercise to the women who have just delivered their babies is very beneficial because it can increase circulation which reduces perineum Pain and it can accelerate wound healing 22,16

Pelvic floor muscle strengthening exercises are beneficial for basic pelvic elasticity for healing the uterus, stomach, muscles around the vagina and injured hip muscles and for accelerating the return of these body parts to normal shape as well as for blood circulation. It can also normalize the loosing joints due to pregnancy and childbirth and can prevent further weakness and stretching. In addition, it also generates psychological benefits, increases the ability to deal with stress and helps them relaxed since it reduced postpartum depression ${ }^{23}$

Pelvic floor muscle training can prevent perineum tearing $^{24}$, can reduce the likelihood of urinary problems ${ }^{21}$, such as postpartum incontinence, can reduce the risk of hemorrhoids, can facilitate labor ${ }^{25}$, and can heal perineum wounds ${ }^{8}$. Postpartum exercises including pelvic floor exercises combined with abdominal exercises will improve blood circulation to the perineum so that it will reduce swelling and pain perineum ${ }^{26}$. Besides, it will increase healing and eliminate inflammatory exudates which will further reduce pain because the muscles have stretched. Therefore, it is important to contract and relax pelvic floor muscles, especially basic muscles the pelvis where this exercise should be the number of contractions must be increased to 50 per day in small groups of five at a time and is associated with daily activities23. The best exercises for pelvic floor muscles are those that hold the legs and head on the floor, or only one leg is lifted at a time, and these exercises can be combined with lower abdominal exercises 7 , they will also cause muscle excitation which will cause an increase in calcium cytosol, especially from extracellular fluid, then there will be a biochemical reaction that is colmodulin (cell protein) associated with calcium will cause the myosin light chain kinase to become active so that the crossed bridge of myosin is phosphoryzed so that the binding of actin and myosin occurs, then contraction occurs. ${ }^{7}$

From the results of this study, it was found that there were also 15 people with perineum Pain results after exercise lower than before exercises. It was also found that there was 1 person actually experienced an increase in pain than before exercise. From the data obtained by 1 person is multiparity, and experienced perineal rupture. This can be happened since that mother with multiparity had already experienced previous pain before or a long time ago. Then, she often experiences a series of episodes of pain 
without ever recovering or suffering from severe pain and experiences a raise of anxiety, this will cause this woman to have difficulty interpreting the existing pain. ${ }^{14}$

The results of previous research entitled "The Effectiveness of Kegel exercises and deep breathing relaxation against perineum pain" showed that the average of perineum Pain in post-partum mothers before Kegel exercises was 4.73 . While in this study, it was found that the mean before the exercise was 3.94, then it was 1.62 after exercise. It means that it decreased by 1.32 . Therefore, it can been proven that pelvic floor exercises combined with abdominal muscles are more effective in reducing after perineum pain.

\section{CONCLUSIONS AND RECOMMENDATION}

Pelvic and abdominal muscle exercises are effective in reducing perineum pain in mothers after childbirth, so it is expected that postpartum mothers can do pelvic floor and abdominal muscle exercises as soon as they feel comfortable. Health workers are suggested to have a standard operating procedure related to this exercise so that they can apply this treatment in health services especially in the puerperal ward.

\section{REFERENCES}

1. Romano M, Cacciatore A, Giordano R, La Rosa B. Postpartum period: three distinct but Corresponding Author: $J$ Prenat Med. 2010;4(2):22-25.

2. Smith LA, Price N, Simonite V, Burns EE. Incidence of and risk factors for perineal trauma: A prospective observational study. BMC Pregnancy Childbirth. 2013;13(1):1. doi:10.1186/1471-239313-59

3. Tiran D. Myles Text Book. Myles text $B$. 2014;16(1):74. doi:10.1016/s1353 6117(03)00105-7

4. Senol DK, Aslan E. The Effects of Cold Application to the Perineum on Pain Relief After Vaginal Birth. Asian Nurs Res (Korean Soc Nurs Sci). 2017;11(4):276-282.

doi:10.1016/j.anr.2017.11.001

5. Kusyati E, Hidayah N. Efektivitas Senam Kegel Dan Relaksasi Nafas Dalam Terhadap Nyeri Perineum Pada lbu Post Partum. 26. doi:10.1016/j.egypro.2017.03.276

6. Mahmoodi F, Mobaraki A. Assessment of effects of Kegel exercises on reduction of perineum Pain after episiotomy in primiparous women. Iran $J$ Obstet Gynecol Infertil. 2014;17:18-25.

7. Neumann P, Gill V. Pelvic floor and abdominal muscle interaction: EMG activity and intraabdominal pressure. Int Urogynecol J. 2002;13(2):125-132. doi:10.1007/s001920200027

8. Anwar S. Efek Latihan Kegel pada Kekuatan Otot Dasar Panggul Ibu Pasca Persalinan The Effect of Kegel Exercise on Pelvic Floor Muscle Strength in Post Delivery Mother. 2016;26(2):120-123.
9. Ulfa M. Efektivitas Kombinasi Latihan Otot Dasar Panggul Dan Perut Terhadap Involusio Uteri Pada Ibu Nifas. 2013:127-135.

10. Dahlan MS. Statistik Untuk Kedokteran Dan Kesehatan: Deskriptif, Bivariat, Dan Multivariat, Dilengkapi Dengan Aplikasi Menggunakan SPSS.; 2011.

11. Hidayat A. Menghitung Besar Sampel Penelitian. Metodologi. 2012:1. https://www.statistikian.com/2012/08/menghitungbesar-sampel-penelitian.html.

12. Mansur SN, Wantania FE, Surachmanto E. Hubungan antara kadar asam urat dengan tekanan darah pada mahasiswa pria obesitas sentral fakultas kedokteran universitas sam ratulangi manado. e-CliniC. 2015. doi:10.35790/ecl.3.1.2015.7392

13. Klimek L, Tilo KB, Jean B, et al. Visual analogue scales (VAS ): Measuring instruments for the documentation of symptoms and therapy monitoring in cases of allergic rhinitis in everyday health care Position Paper of the German Society of Allergology ( AeDA ) and the German Society of All. Allergo J Int. 2017;26(1):16-24. doi:10.1007/s40629-016-0006-7

14. Penny Simkin. Panduan lengkap kehamilan, melahirkan dan bayi. Pandu lengkap kehamilan, melahirkan dan bayi. 2008. doi:10.1017/CBO9781107415324.004

15. Agung JT. The Difference Result of Perineal Massage and Kegel Exercise toward Preventing of Perineal Laceration during Labor Perbedaan Hasil Masase Perineum dan Kegel Exercise terhadap Pencegahan Robekan Perineum pada Persalinan di Bidan Sri Rahayu Sri Sumarni Umar. 2015;4(2):728-733.

16. Roy P, M.S. S, Biswas B, Chatterjee A, Roy P. A comparative study of perineal morbidity in vaginal delivery with and without episiotomy. Int J Reprod Contraception, Obstet Gynecol. 2015;4(5):14421445. doi:10.18203/2320-1770.ijrcog20150727

17. Smith LA, Price N, Simonite V, Burns EE. Incidence of and risk factors for perineal trauma: A prospective observational study. BMC Pregnancy Childbirth. 2013;13:1-9. doi:10.1186/1471-239313-59

18. Triwik Srimulati DS. Pengaruh Derajat Robekan Perineum Terhadap Skala Nyeri Perineum Pada Ibu Nifas Di Kabupaten Wonogiri Triwik Sri Mulati, Dewi Susilowati. 2018:51-56.

19. Leeman L, Fullilove AM, Borders N, Manocchio R, Albers LL, Rogers RG. Postpartum perineum Pain in a low episiotomy setting: Association with severity of genital trauma, labor care, and birth variables. Birth. 2009. doi:10.1111/j.1523536X.2009.00355.X

20. East CE, Sherburn M, Nagle C, Said J, Forster D. Perineum Pain following childbirth: Prevalence, effects on postnatal recovery and analgesia usage. Midwifery. doi:10.1016/j.midw.2010.11.009

21. Jayanti N putu ayu. Pengaruh Senam Kegel Dan Pijat Perineum Terhadap Kekuatan Otot Dasar Panggul Lansia. 2008:27-33.

22. Lubis DL, Obstetri D, Ginekologi DAN. Kekuatan 
otot dasar panggul pada wanita pasca persalinan. 2009.

23. Markwell SJ. Physical therapy management of pelvi/perineal and perianal pain syndromes. World J Urol. 2001;19(3):200-207.

24. Leeman L, Rogers R, Borders N, Teaf D, Qualls C. The Effect of Perineal Lacerations on Pelvic Floor Function and Anatomy at 6 Months Postpartum in a Prospective Cohort of Nulliparous Women. Birth. 2016. doi:10.1111/birt.12258

25. Physiotherapy PO\& G. The Pelvic Floor Muscles A Guide for Women. Gilbraltar Heal Auth. 2017:112.

26. Simkin P, Whalley J. Panduan Lengkap Kehamilan, Melahirkan, \& Bayi. 2008:278. 